De los Palos-Peña, M., Solís-Marín, F.A., Laguarda-

Figueras, A., \& Durán-González. A. (2021).

Ontogenetic variation of the odontophore of Luidia

superba (Asteroidea: Paxillosida) and its taxonomic implications. Revista de Biología Tropical, 69(S1), 89-100. DOI 10.15517/rbt.v69iSuppl.1.46330

DOI 10.15517/rbt.v69iSuppl.1.46330

\title{
Ontogenetic variation of the odontophore of Luidia superba (Asteroidea: Paxillosida) and its taxonomic implications
}

\author{
Magdalena De los Palos-Peña ${ }^{1 *}$; (D) https://orcid.org/0000-0002-9667-8670 \\ Francisco Alonso Solís-Marín²; (D) https://orcid.org/0000-0001-5729-3316 \\ Alfredo Laguarda-Figueras ${ }^{2}$ \\ Alicia Durán-González ${ }^{2}$
}

1. Posgrado en Ciencias del Mar y Limnología, Universidad Nacional Autónoma de México, México; mdelospalos@ciencias.unam.mx (*Correspondence).

2. Laboratorio de Sistemática y Ecología de Equinodermos, Instituto de Ciencias del Mar y Limnología, Universidad Nacional Autónoma de México, México; fasolis@cmarl.unam.mx; laguarda@cmarl.unam.mx; aliciad@cmarl.unam.mx

\author{
Received 17-VI-2020. Corrected 14-IX-2020. Accepted 05-X-2020.
}

\begin{abstract}
Introduction: The sea star odontophore is the structure positioned between the paired oral ossicles, with which they articulate through proximal and distal processes. The internal anatomy structures may be used as taxonomic characters for a precise differentiation between species, so it is necessary to describe the structures variation throughout growth. Objective: To describe the odontophore shape and variation of Luidia superba A. H. Clark, 1917 from specimens of the Gulf of California deposited in the Echinoderm National Collection, ICML UNAM. Methods: A total of 735 specimens were examined to describe the external characters, from which 55 selected specimens, within a range of $\mathrm{R}=14 \mathrm{~mm}$ and $\mathrm{R}=210 \mathrm{~mm}$, were dissected to extract the odontophores and analyzed with geometric morphometrics. Results: Scanning electronic microscopy (SEM) images of the odontophores showing the variations in shape throughout growth are presented. Differences in shape between size groups were confirmed with a Canonical Variables Analysis $(\mathrm{P}<0.05)$. Conclusions: There are three main groups in this size ranges where specialization of the stereom can be observed through the ontogenetic series; the variation in shape of the odontophore shown here is a precedent for the use of internal anatomy as new taxonomic characters of identification.
\end{abstract}

Key words: Ossicles; morphology; oral frame; internal anatomy; geometric morphometrics; Scanning Electron Microscopy.

The genus Luidia Forbes, 1839 is composed of infaunal organisms; they usually inhabit shallow waters and reefs on the continental shelf, although some species can extend to the upper batial zone. They are generally more active and agile than other starfish, and feed primarily on small mollusks and other echinoderms. They are characterized by having
5-11 quite long arms, which narrow distally (Downey, 1973; A.M. Clark \& Downey, 1992; Benavides-Serrato, Borrero-Pérez, \& DíazSánchez, 2011).

Species of this genus are distributed in all oceans from the tropics to high temperate latitudes. Some species have a wider distribution, while others have a more restricted one 
(Sladen, 1889; A.M. Clark \& Downey, 1992; Puppin-Gonçalves, Rocha, Alencar, Moraes, Araújo \& Freire, 2020). The known morphological characteristics of the organisms that are associated with the particulate nature of the substrate they inhabit are mainly the shape and arrangement of the ambulacral feet and paxillae. These organisms are buried in the substrate, so it has been suggested that the rounded tip of the feet is adapted to push between the particles of the substrate and contribute to an efficient movement (Blake, 1989; Lawrence, 2013).

Organisms of this genus are intraoral feeders, which may be related to their presence in particulate substrates where most of the available food corresponds mainly to infaunal organisms, such as foraminifera. They do not have the ability to separate the small infauna from the sediment while feeding; the cardiac stomach is very large, which gives them the ability to ingest very large prey (Hulings \& Hemlay, 1963; Jangoux 1982a; Jangoux 1982b; Lawrence, 2013). The mouth frame is composed of ten pairs of oral and circumoral muscles and five unpaired interradial odontophores. This was described by Viguier in 1878, and he suggested that more precise characters may be derived from the oral frame and the internal anatomy. The odontophore is made up of symmetrical, paired, distal, and proximal processes which articulate with the inner surface of the oral plates and an actinal keel to which the fibers of the odontophore-oral muscle attach (Gale, 2011).

Luidia superba A.H. Clark, 1917 is the largest species of the genus in the Pacific, and the largest specimen so far reported $(\mathrm{R}=415$ $\mathrm{mm}$ ) was collected in Galapagos (Downey \& Wellington, 1978) and deposited in the United States National Museum, Smithsonian Institution (USNM E18920). This species is distributed from the Gulf of California to Peru (Alvarado \& Solís-Marín, 2013). Although no studies have been conducted on the feeding habits of this species, it is known that other members of the genus are effective predators, so it is necessary to carry out studies on their anatomy and the intraspecific latitudinal variation that exists among specimens of the Gulf of California to Peru. It is likely that a successful predator, such as a luidid, needs a developed oral system, since the five pairs of interradial muscles, five radial pairs, the five transverse actinal muscles on the circumorals, and the five odontophore-oral muscles (Fig. 1) close the peristome by contracting.

The odontophore plays an important role in the oral frame, since together with the oral ossicles, are responsible for the opening movement of the mouth, which allows organisms feeding. Blake (1973) described that the ontogenetic variation is greater than variation between conspecific individuals of similar size, and that there is variation in age and size of the various ossicles of an arm series, but he did not discuss this for the oral ossicles. It is necessary to describe the variation of the odontophore throughout its growth, especially in species that have a wide range of sizes such as this one.

Studies on ossicle morphology are common in other echinoderm groups, such as ophiuroids (Thuy \& Stöhr, 2016; Hendler, 2018; Alitto, Granadier, Christensen, O’Hara, Domenico \& Borges, 2020). For asteroids, the taxonomic usefulness of the individual elements and interpretations of evolutionary relationships have not been completely explored. The goal of this study is to describe the ontogenetic variation of the odontophore shape of Luidia superba in the Gulf of California from specimens deposited in the Echinoderm National Collection, Instituto de Ciencias del Mar y Limología, Universidad Nacional Autónoma de México (ICML, UNAM) as a first approach to evaluate the possibility of using it as a taxonomic character for differentiation at specific level.

\section{MATERIALS AND METHODS}

Specimen examination: We examined all the available specimens of $L$. superba deposited in the Echinoderm National Collection ICML (UNAM) and the National Museum of Natural History, Smithsonian Institution (USNM), Washington D. C. (735 specimens in total). Organisms were observed using a 
stereoscopic microscope Olympus SZX7 and measured using a digital caliper (TRUPER Caldi-6MP), the following measurements were taken: $\mathrm{R}, \mathrm{r}$, arm length $\left(\mathrm{L}_{\mathrm{A}}\right)$ and arm width at the base $\left(\mathrm{B}_{\mathrm{A}}\right)$. They were also photographed using a multifocal microscope LEICA Z16 APOA at the Laboratorio Nacional de Microscopía y Fotografía de la Biodiversidad (Instituto de Biología, UNAM). After reviewing the external characters of the available material to make the description, 55 of the Echinoderm National Collection (ICML-UNAM) specimens were selected to represent the size range that this species reaches in the Gulf of California; the selected specimens range from $\mathrm{R}=14 \mathrm{~mm}$ to $\mathrm{R}=210 \mathrm{~mm}$. We used the anatomical conventions to describe ossicle orientation and nomenclature described by Gale (2011) and Fau and Villier (2018): doda: distal oral/odontophore articulation on the oral; odom: odontophoreoral muscle; poda: proximal odontophore-oral articulation (Fig. 1).

Scanning Electron Microscopy (SEM): A small cut was made on the actinal face of the disc to remove one of the five pairs of oral plates and an odontophore. Arms are designated by Carpenter's system, with " $\mathrm{A}$ " being the arm opposite the madreporite and the other

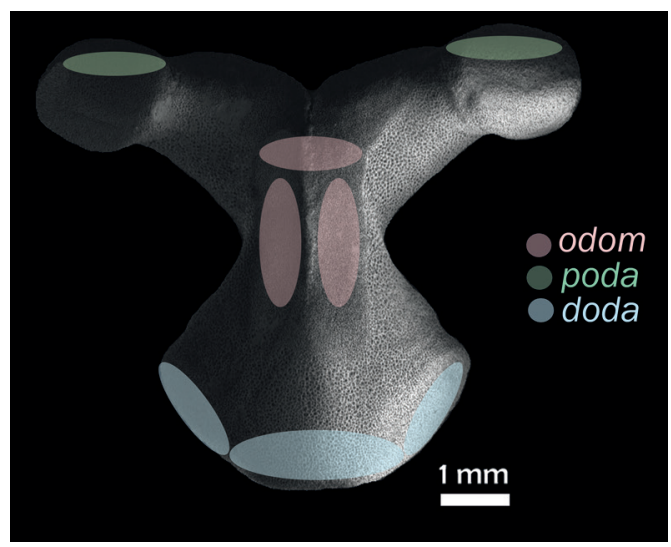

Fig. 1. Scanning electron microscopy (SEM) image of the odontophore in actinal view (ICML-UNAM 1647). In green: insertion of poda (proximal odontophoreoral articulation); in pink: insertion of the muscle odom (odontophore-oral muscle); in blue: insertion of doda (distal oral/odontophore articulation). rays being designated "B", "C", "D", and "E" clockwise when viewed from the oral side (O’Neill, 1989; Lawrence, 2013). To standardize the odontophore selected per specimen, the pair of plates found in the interradium between arms " $C$ " and " $D$ " (the arms between which the madreporite is found) was taken in each specimen. The dissection of the selected specimens was carried out using the method described by Fau and Villier (2018): specimens were prepared in a dilute solution of $\mathrm{NaClO}$ (household bleach) followed by several rinsings with tap water and alcohol $(70 \%)$; they were then dried, mounted and gold-coated on a SEM stub at the Laboratorio Nacional de Microscopía y Fotografía de la Biodiversidad (Instituto de Biología, UNAM) and at the National Museum of Natural History SEM Laboratory (USNM).

Geometric morphometrics: The SEM images of the actinal view of the odontophore were analyzed using geometric morphometrics with specialized software: TPSUtil, TPSDig, CoordGen, PCAGen, CVAGen. A TPS file was built with the images. Subsequently, 14 landmarks and eight semi-landmarks were digitized to define the perimeter of the plate, giving a total of 22 marks; the eight semilandmarks are the ones defining de odontophore "waist". A Procrustes fit was performed and then a Principal Component Analysis (PCA) in order to simplify the description of the variation between ossicles and a Canonical Variables Analysis (CVA) to explore the morphological differences between five ontogenetic categories (Table 1). The categories are made up of 11 specimens each, which were defined based on the available material of each size between

TABLE 1

List of categories, size range and number of specimens per category

\begin{tabular}{ccc} 
Category & Size interval $(\mathrm{r} \mathrm{mm})$ & \# Specimens \\
1 & $14.07-40.13$ & 11 \\
2 & $42.93-51.96$ & 11 \\
3 & $52.61-80.12$ & 11 \\
4 & $84.03-130.5$ & 11 \\
5 & $138.7-210.5$ & 11 \\
\hline
\end{tabular}


$14-210 \mathrm{~mm}$, in other words, from the smallest to the largest size available from the Gulf of California material. P values were calculated using a MANOVA permutation test based on 1000 permutations.

\section{RESULTS}

\section{Systematics}

Luidia superba A. H. Clark, 1917 (Fig. 2 A-F)

Luidia superba A. H. Clark (1917): 171; Caso (1943): 37; (1961): 41; (1979): 205; (1994): 36; Downey \& Wellington (1978): 375; Granja-Fernández et al. (2015): 91; Alvarado et al. (2009): 3; Alvarado \& Solís-Marín (2013): 547; Martín-Cao-Romero et al. (2017): s171.

Luidia (Alternaster) superba: Maluf (1991): 348; Solís-Marín et al. (2005): 125; Benítez-Villalobos et al. (2008): 78; HoneyEscandón et al. (2008): 59.

Diagnosis (Modified from Clark, 1917): $\mathrm{R}=205 \mathrm{~mm}, \mathrm{r}=30 \mathrm{~mm}, \mathrm{R} / \mathrm{r}=6.8$. Five or six arms relatively stout gradually tapering to a blunt extremity; superomarginal paxillae squared, correspond to the inferomarginals; four rows of lateral paxillae on each side of the arm; in the third row, every third or fourth paxillae is much enlarged and bears a stout conical central spine; the central third of the arm is occupied by small, irregular, rounded paxillae, many of which may bear a spine too; inferomarginal plates bear three long stout spines, the lowest being the longest, and on the actinal surface there are three to five spines much shorter and decreasing in size toward the ambulacral groove; actinal intermediate plates have a single prominent median spine; adambulacral plates bear four spines; oral plates narrow with 11 gradually decreasing spines situated along the median suture and four similar spines situated along the furrow margin; no pedicellariae.

Description: Five arms, $\mathrm{R}=15.38-415$ $\mathrm{mm}, \mathrm{r}=2.96-49 \mathrm{~mm}, \mathrm{R} / \mathrm{r}=4.02-9.59$, average $\mathrm{R} / \mathrm{r}=5.94$. Small disk, five long flattened arms that taper slightly to a rounded tip $\left(\mathrm{L}_{\mathrm{A}}=\right.$ 12.01-363 mm; $\left.\mathrm{B}_{\mathrm{A}}=3.83-48 \mathrm{~mm}\right)$. Paxillae of the center of the disk rounded with six to nine central spinelets surrounded by 18 to 20 slender peripheral ones (Fig. 2A); 15 to 19 paxillae transversally, in the middle section of the arm very small and irregular paxillae, mixed with some enlarged ones that occasionally bear a central conical spine (Fig. 2C), these enlarged paxillae are irregularly distributed on the arm; lateral paxillae squared in shape. Three to four rows of lateral paxillae on each side of the arm (Fig. 2E); lateral paxillae square with rounded edges; superomarginal paxillae similar in shape, slightly larger, with 30 stout central spinelets approximately and up to 40 peripheral spinelets; madreporite small, rounded and hidden in the interradius between the first three rows of lateral paxillae, there may be a couple of adjacent bigger paxillae that surround it; terminal plate rounded, almost completely abactinal, covered with fine granules; inferomarginal plates long and narrow, with three long spines and three to five smaller ones on the actinal surface of the plate (Fig. 2F); three adambulacral spines and there may be a fourth small one behind the last one (Fig. 2D); eight to ten oral spines, central ones longer; six to eight suboral smaller spines which decrease in size toward the distal section of the plate; no pedicellariae.

Material examined: Holotype USNM36948, Albatross st. 2797 Panama, (86'29.8” N \& 78 50'59.9” W) 60 m; USNM-36948, one specimen, Panama $\left(8^{\circ} 6{ }^{\prime} 29.8^{\prime \prime} \mathrm{N} \&\right.$ 78०50'59.9" W) $60 \mathrm{~m}$; USNM-E18920, two specimens, Galapagos Islands, Ecuador (?) 9-18 m; USNM-E41830, one specimen, Galapagos islands (?) depth?; SONORA: ICMLUNAM 2582, one specimen, $\left(26^{\circ} 38^{\prime} 00^{\prime \prime} \mathrm{N} \&\right.$ $112^{\circ} 31^{\prime} 00^{\prime \prime}$ W) depth?; ICML-UNAM 4419, two specimens, $\left(30^{\circ} 59^{\prime} 00^{\prime \prime} \mathrm{N} \& 114^{\circ} 3^{\prime} 1^{\prime \prime} \mathrm{W}\right)$ $95 \mathrm{~m}$; ICML-UNAM 2342, one specimen, ( $\left.27^{\circ} 55^{\prime} 00^{\prime \prime} \mathrm{N} \& 111^{\circ} 0^{\prime} 00^{\prime \prime} \mathrm{W}\right)$ depth?; ICMLUNAM 4426, two specimens, (300'9" N \& $112^{\circ} 54^{\prime} 60$ ” W) 103 m; ICML-UNAM 3569, 15 specimens, (2651'04" N \& 1106'3" W) $48 \mathrm{~m}$; ICML-UNAM 4239, 33 specimens, (28 20'0' $\mathrm{N} \& 111^{\circ} 35^{\prime} 0^{\prime \prime}$ W) $30 \mathrm{~m}$; ICML-UNAM 4414, two specimens, $\left(26^{\circ} 58^{\prime} 16^{\prime \prime} \mathrm{N} \& 110^{\circ} 3\right.$ ' $\left.25^{\prime \prime} \mathrm{W}\right)$ $19.5 \mathrm{~m}$; ICML-UNAM 4388, one specimen, 

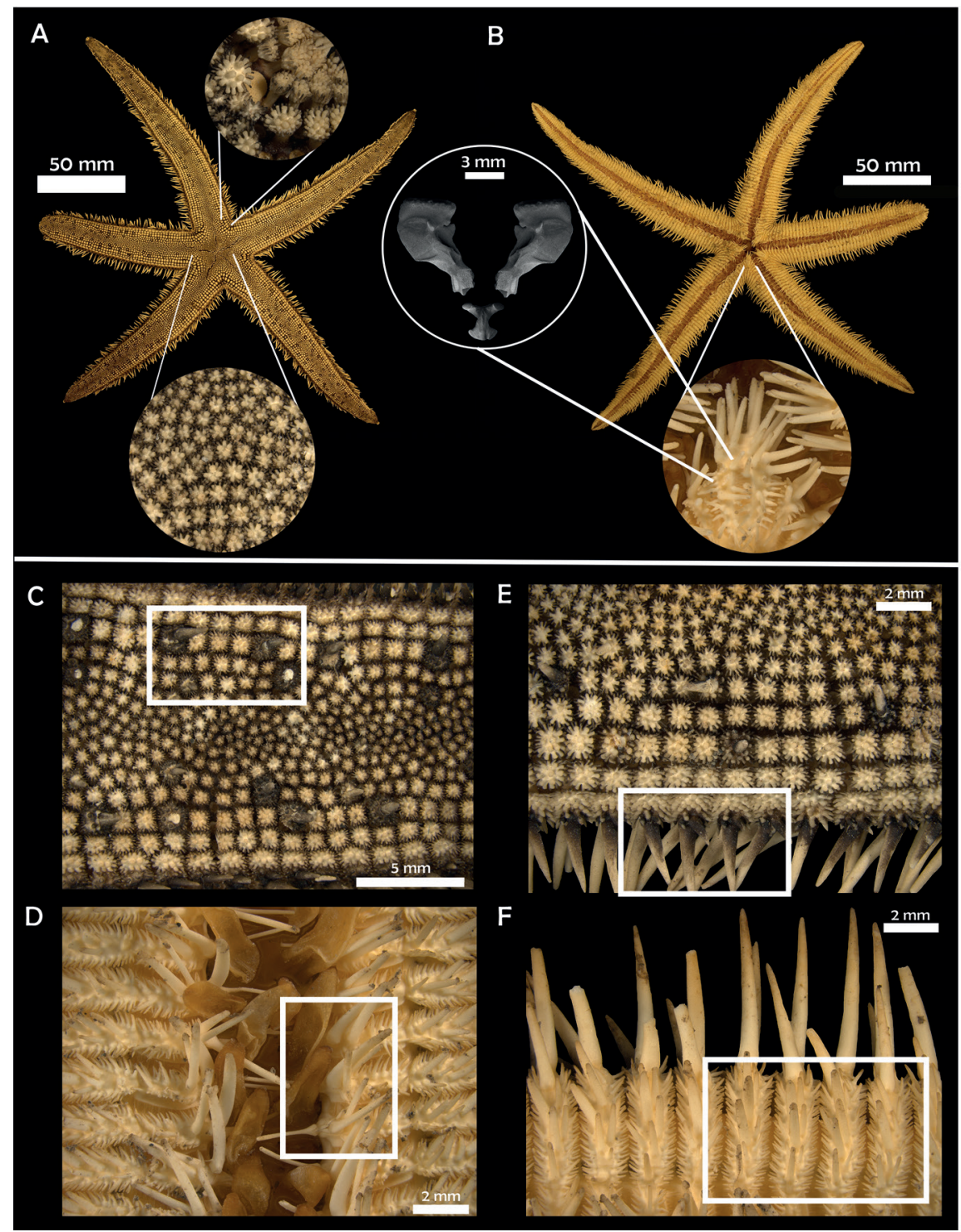

Fig. 2. Luidia superba A.H. Clark, 1917. (ICML-UNAM 3569). A-B. Actinal and abactinal view. A. Central paxillae. B. Detail of oral plates and odontophore (SEM). C. Paxillae central spine. D. Detail of adambulacral plates. E. Detail of lateral and superomarginal paxillae, marginal spines. F. Detail of inferomarginal spines.

(2651'3" N \& 1106'5" W) $47.7 \mathrm{~m}$; ICMLUNAM 4238, 320 specimens, (28 $20^{\prime} 0^{\prime \prime} \mathrm{N}$ \& 111 $35^{\circ} 0^{\prime \prime}$ W) 29.9-31 m; ICML-UNAM 3555 , ten specimens, (26 $51^{\circ} 4^{\prime \prime} \& 110^{\circ} 6$ ' 3 " W) $53 \mathrm{~m}$; ICML-UNAM 4244, six specimens, (28 $16^{\prime} 16^{\prime \prime} \mathrm{N} \& 111^{\circ} 36^{\prime} 79^{\prime \prime}$ W) $57 \mathrm{~m}$; ICMLUNAM 4423, 24 specimens, (26 $51^{\circ} 4^{\prime \prime} \mathrm{N} \&$ $110^{\circ} 6$ '3” W) 19.5 m; ICML-UNAM 4197, 23 specimens, (2651'4" N \& 110 6'3" W) $47.7 \mathrm{~m}$; ICML-UNAM3627, one specimen, (26 $51^{\circ} 4^{\prime \prime}$ ' $\mathrm{N} \& 110^{\circ} 6^{\prime} 3$ " W) $23 \mathrm{~m}$; ICML-UNAM 4208, 22 specimens, $\left(28^{\circ} 20^{\prime} 0^{\prime \prime} \mathrm{N} \& 111^{\circ} 35^{\prime} 0^{\prime \prime}\right.$ 'W) $57 \mathrm{~m}$; ICML-UNAM 4211, 182 specimens, $\left(28^{\circ} 20^{\prime} 0\right.$ " N \& $111^{\circ} 35^{\prime} 0^{\prime \prime}$ W) $58 \mathrm{~m}$; ICMLUNAM 3621, five specimens, (28 $20^{\prime} 0^{\prime \prime}$ N \& $111^{\circ} 35^{\prime} 0$ "' W) 54 m; ICML-UNAM 1647, eight 
specimens, Mazatlán, Mexico (2240’00” N \& $\left.105^{\circ} 55^{\prime} 00^{\prime \prime} \mathrm{W}\right)$ depth?; ICML-UNAM 4399, 25 specimens, Gulf of California (29 $27^{\prime} 14^{\prime \prime} \mathrm{N}$ \& 112 29'10" W) 40 m; ICML-UNAM 3002, one specimen, Colima, Mexico (19 $7^{\circ} 00^{\prime \prime} \mathrm{N} \&$ $104^{\circ} 21^{\prime} 00$ ” W) depth?; ICML-UNAM 4410, 14 specimens, Baja California Sur, Gulf of California $\left(26^{\circ} 58^{\prime} 82^{\prime \prime} \mathrm{N} \& 111^{\circ} 53^{\prime} 60^{\prime}\right.$ 'W) 64.2 m; ICML-UNAM 4425, six specimens, Baja California Sur, Gulf of California (26 $58^{\circ} 82^{\prime}$ ' $\mathrm{N} \& 111^{\circ} 53^{\prime} 60^{\prime \prime}$ W) $64.2 \mathrm{~m}$; ICML-UNAM 4429 , eight specimens, Tiburon Island, Gulf of

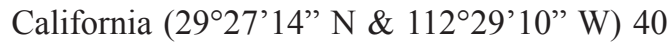
m; ICML-UNAM 4406, four specimens, Tiburon Island, Gulf of California $\left(29^{\circ} 27^{\prime} 14^{\prime \prime} \mathrm{N} \&\right.$ $112^{\circ} 29^{\prime} 10^{\prime \prime}$ W) 40 m; ICML-UNAM 4422, two specimens, San Miguel Cape, Baja California, Mexico (288'24" N \& 11246'21'” W) 48 m; ICML-UNAM 7523, one specimen, Rosario, Oaxaca, Mexico (1554'1” N \& 95 41'30” W) depth?; ICML-UNAM 4582, six specimens, Baja California Sur, Mexico (2659'9.7' N \& 11153'26.9”'W) 63.3 m; ICML-UNAM 7779, one specimen, Gulf of Tehuantepec, Oaxaca, Mexico (16 $\left.18^{\circ} 0^{\prime \prime} \mathrm{N} \& 95^{\circ} 10^{\prime} 0^{\prime \prime} \mathrm{W}\right)$ depth?; ICML-UNAM 1646, one specimen, Mazatlán, Mexico (22 $40^{\circ} 0^{\prime \prime} \mathrm{N} \& 105^{\circ} 55^{\prime} 0^{\prime \prime}$ W) depth?; ICML-UNAM 4577, one specimen, Del Carmen Island, Gulf of California $\left(25^{\circ} 58^{\prime} 14\right.$ " N \& 111 ${ }^{\circ} ' 23$ ” W) $37 \mathrm{~m}$; ICML-UNAM 4218, one specimen, Santa María, Sinaloa, Mexico $\left(25^{\circ} 7^{\prime} 0 "\right.$ " N \& $108^{\circ} 20^{\prime} 0$ " W) $22.8 \mathrm{~m}$; ICMLUNAM 2562, one specimen, Los Angeles Bay, Baja California N, Mexico ( ? ) depth?.

Geographic and bathymetric distribution: Mexico: Gulf of California, Sinaloa, Oaxaca, Gulf of Tehuantepec; Panama; Colombia; Galapagos, Ecuador, and Peru. From 3 to $250 \mathrm{~m}$ (Clark, 1989; Alvarado \& Solís-Marín, 2013).

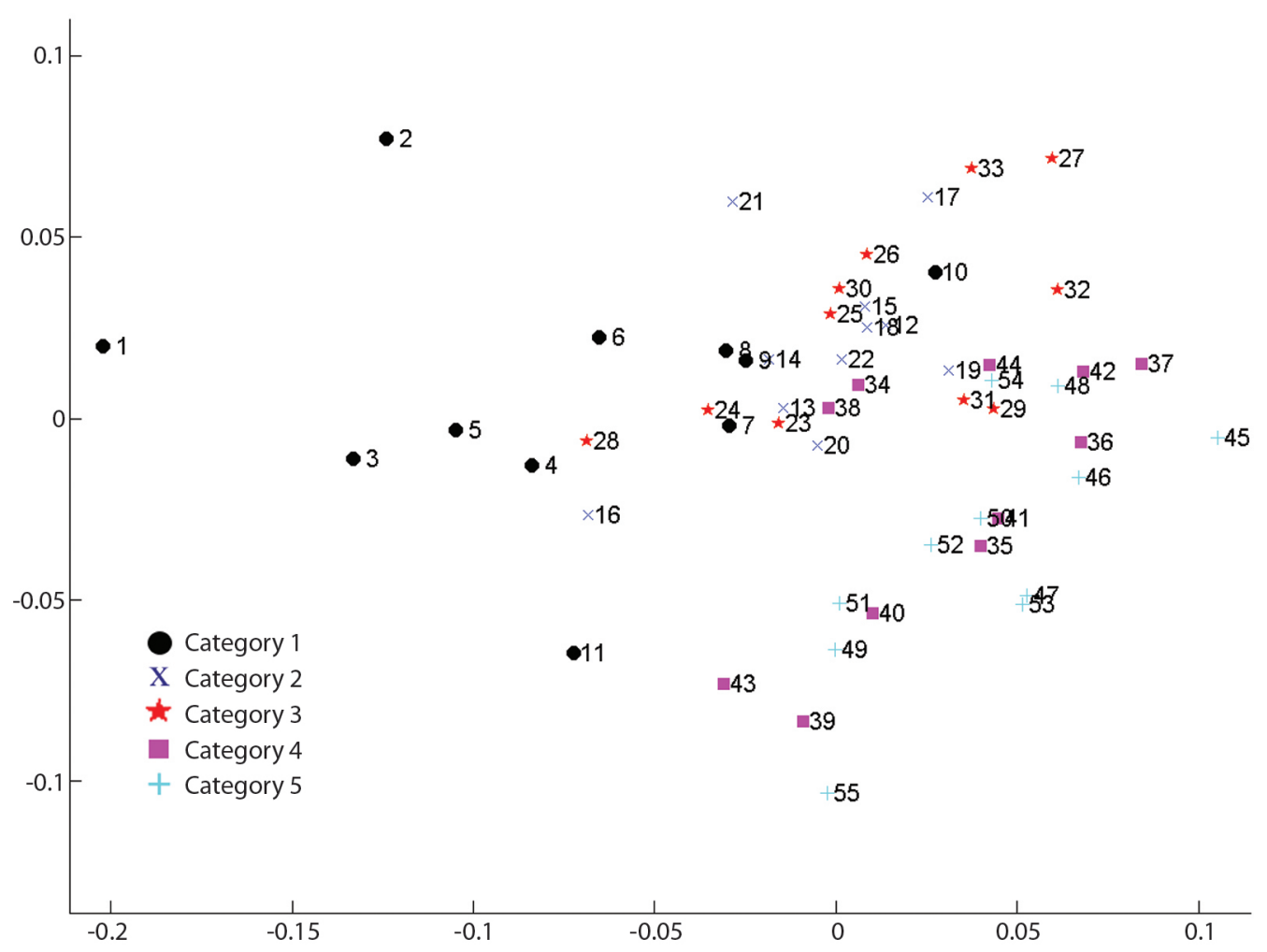

Fig. 3. PCA plot. Variance explained by the two first components. The number of significant eigenvalues is $1 . \mathrm{X}^{2}=8.2861,4.2862$. 
Remarks: The holotype has six arms; however, Downey and Wellington (1978) reported that this is not normal for the species, since the ones observed and collected in Galapagos have five arms. All the examined specimens in the present study have five arms as well. Clark (1917) mentioned that the Albatross st. 2797 was in Colombia but according to the geographic coordinates, it is in Panama.

Geometric morphometrics: PCA results showed that more than $50 \%$ of the variance $(0.007999)$ is explained by the first two components (PC $1=0.4241 ; \mathrm{PC} 2=0.1918$ ) (Fig. 3). Differences in shape of the odontophore between size groups were confirmed with CVA $(\mathrm{P}<0.05)$ and the deformation grid exhibited the differences along the odontophore keel based on landmark and semi-landmark displacement vectors. As shown in Fig. 4, the shape of the odontophore undergoes the greatest change in the curvature of the lateral notch of the plate (keel) due to the elongation that occurs throughout growth. The result from the MANOVA test $(\mathrm{P}=0.000999)$ based on 1 000 permutations $($ Variance error $=0.005774$ ) and the variance explained by groups was $=0.006009$, so that groups explain $51 \%$ of the total variance. The CVA (Table 2) together with the Mahalanobis distances showed two distinct canonical variables ( $p$ scores $=6.5859 \mathrm{e}-08$, 0.0156715 ) (Table 3), which means there are three significantly distinct groups (Fig. 5). Of the five different categories, two, three and four form a single significant group, which separates organisms into three size ranges from $\mathrm{R}$ $=14.02-40.13 \mathrm{~mm}$ (Fig. 6A), $\mathrm{R}=42.93-130.5$ $\mathrm{mm}$ (Fig. 6B), and $\mathrm{R}=138.7-210 \mathrm{~mm}$ (Fig. $6 C)$. The three significantly different groups were named: S (small specimens), M (medium specimens), L (large specimens).

\section{DISCUSSION}

Using a comparative morphological approach, we provide evidence of three size groups in which the odontophore varies significantly in this species. This study quantified

TABLE 2

Geometric morphometrics results for the age groups, MANOVA results: canonical axes $(\lambda)$, chi square $\left(X^{2}\right)$, freedom degrees (DF) and $p$ values

\begin{tabular}{lllc}
\multicolumn{4}{c}{ MANOVA (CVA) } \\
$1 \lambda=0.0002$ & $\mathrm{X}^{2}=272.89$ & $\mathrm{DF}=160$ & $\mathrm{P}=6.5859$ \\
$2 \lambda=0.0079$ & $\mathrm{X}^{2}=152.31$ & $\mathrm{DF}=117$ & $\mathrm{P}=0.015671$ \\
\hline
\end{tabular}

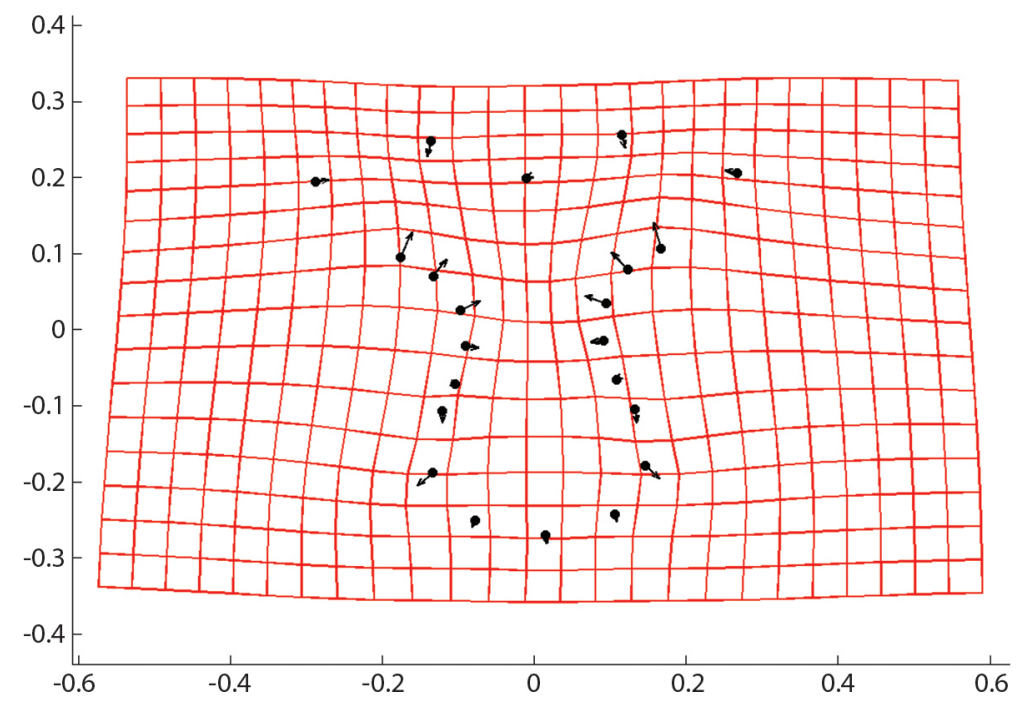

Fig. 4. CVA Deformation grid and vectors showing relative strength of differences in Procrustes-superimposed odontophore shape along CVA axis 1. 
TABLE 3

Mahalanobis distance between a priori group means

\begin{tabular}{ccccc}
1 & 2 & 3 & 4 & 5 \\
0.000000 & 6.898565 & 13.114938 & 13.654911 & 18.854568 \\
6.898565 & 0.000000 & 6.485488 & 8.021896 & 12.693379 \\
13.114938 & 6.485488 & 0.000000 & 8.487616 & 10.550907 \\
13.654911 & 8.021896 & 8.487616 & 0.000000 & 5.331041 \\
18.854568 & 12.693379 & 10.550907 & 5.331041 & 0.000000 \\
\hline
\end{tabular}

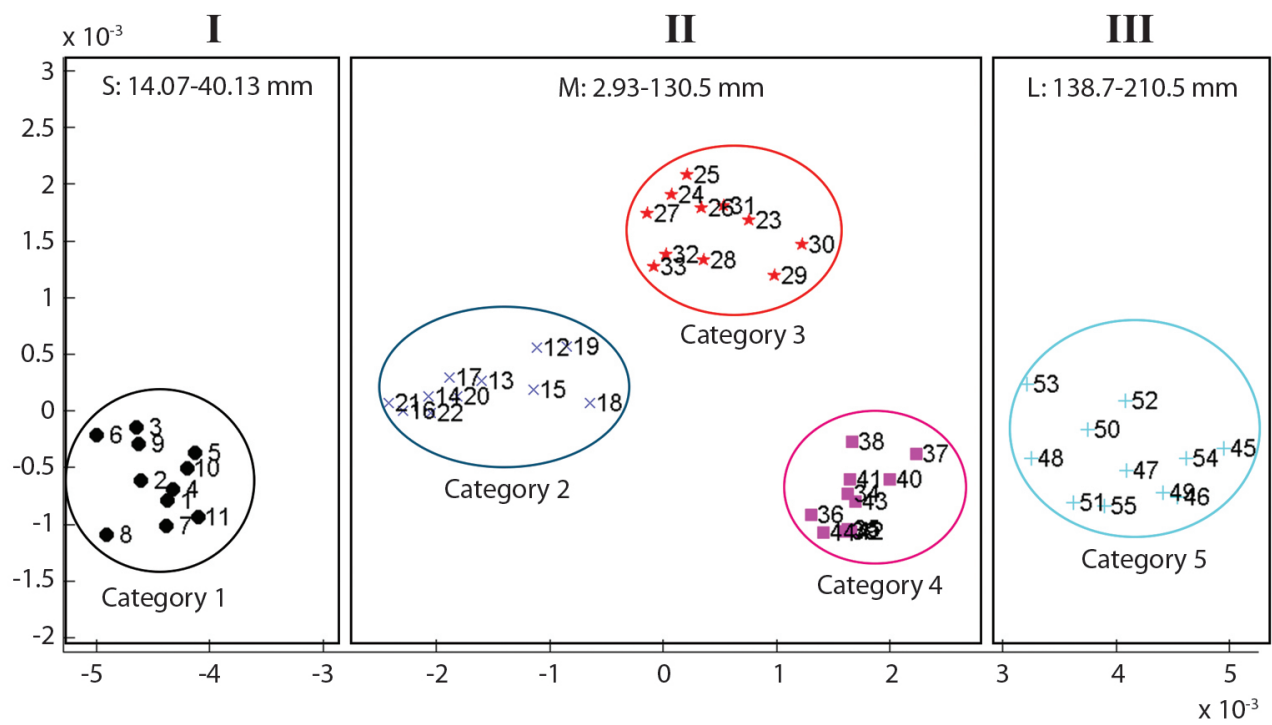

Fig. 5. CVA plot for 55 specimens of $L$. superba. Categories 1-5 are separated in colors, the three distinct groups showed by the analysis are shown in boxes (I, II, III).

the main morphological differences observed between small, medium, and large specimens of Luidia superba. As mentioned by Gale (2015), the odontophore is one of the defining characters of the post-Palaeozoic Neoasteroidea. Viguier (1878) discussed the classification of asteroids and proposed to use the shape of the oral plates and the odontophore to separate taxa, mentioning that Astropecten Gray, 1840, Luidia Forbes, 1839 and Ctenodiscus Müller \& Troschel, 1842 form a natural group. This was the first and only approach to a classification based on this character and was only recently explored by some authors (Gale, 2011; Fau \& Villier, 2018; Fau \& Villier, 2019) for certain groups of asteroids.
Fau and Villier (2018) described the complete ontogenetic development of the skeleton of Zoroaster fulgens Thompson, 1873 using SEM imaging and discussed how the ossicles grow in asteroids though the addition of extracellular calcite deposits. They described that younger ossicles not only have different shapes compared with older, homologous ossicles, but also lack differentiated structures like muscle insertions. The results obtained in this study are similar to that observed in theirs, since the odontophore shows a much simpler general shape in the $\mathrm{S}$ group. Also, while dissecting specimens, these are the first ones to lose all the tissue, which could suggest that the latter is softer, and that the ossicle lack a developed or 

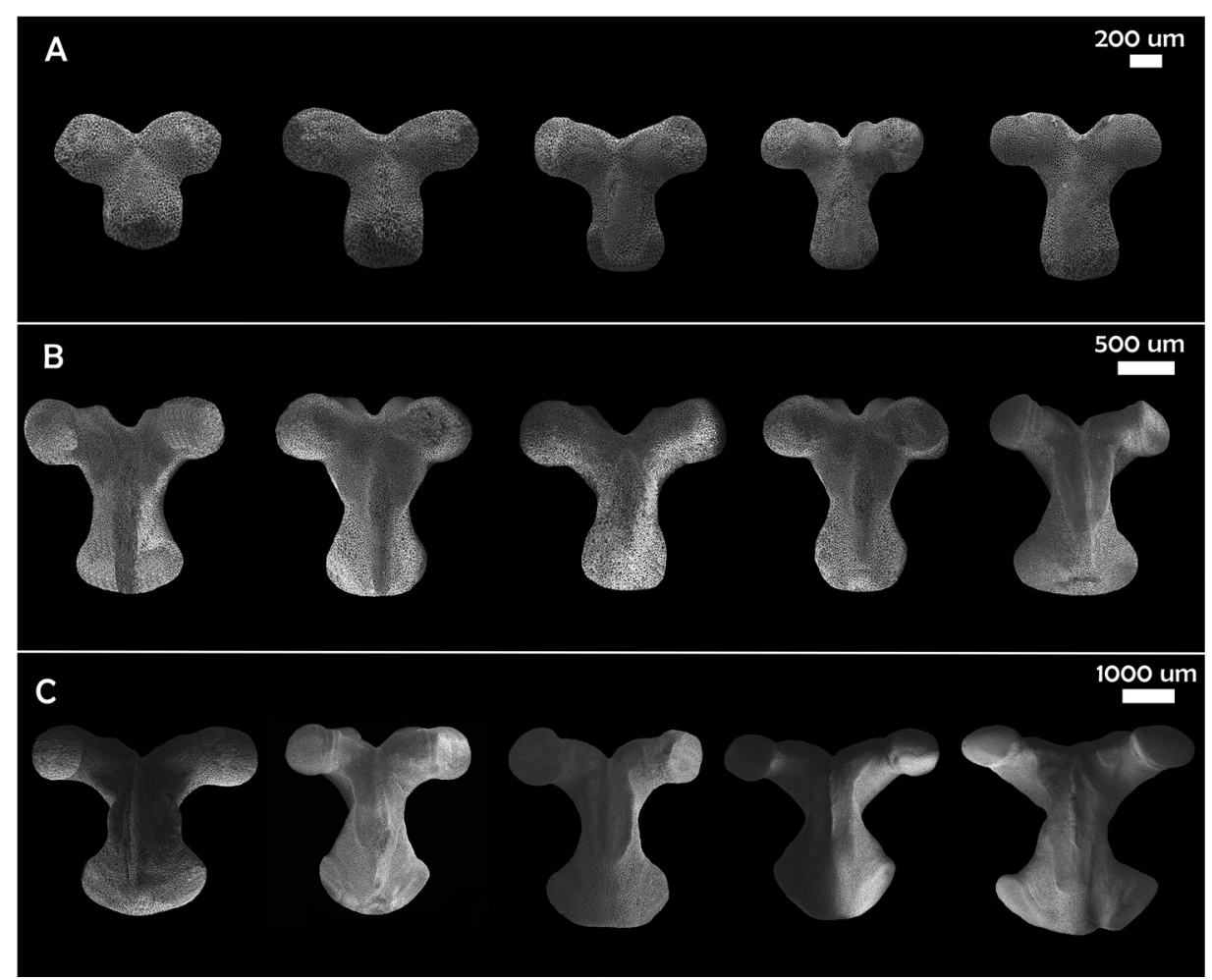

Fig. 6. Variation in shape in the three size groups defined from the CVA results. The shape varies on the sides of the keel and in the elongation of the proximal and distal processes. A. Small specimens, (S). B. Medium specimens (M). C. Large specimens (L).

specialized stereom to allow greater adherence. The gradually specialization of the stereom can be observed through the ontogenetic series.

Our results allowed us to confirm that, as size of the specimen increases, different areas of specialized stereom start to appear (Fig. 5B), for example in the odontophores keel, where the odontophore muscle (odom) inserts. In this case, CVA showed shape is significantly different only between three main groups named small, medium, and large. Stereom becomes thinner where muscles are inserted, so the keel becomes one of the most fragile parts of the plate. The results of our study contrast with those observed by Turner and Dearborn (1972) in Ctenodiscus crispatus Bruzelius, 1805 , since, despite the fact that it is also a member of Paxillosida Perrier, 1884, they reported only slightly ontogenetic variation in the odontophore. This only highlights the need for further studies of this important character.

It must be considered that the odontophore may be indicative of the feeding habits of a species, so the odom may be stronger in some species due to their feeding needs and the size of their preys. This means that the stereom around the keel could be more or less thin. Luidiids are characterized by being efficient predators (Lawrence, 2013) and Luidia superba is a species that shows a large size range, which, based on the stomach content of reviewed specimens, suggests that they are capable of ingesting exceptionally large prey, such as other echinoderms or mollusks. Therefore, despite standardizing the size of the sampled specimens (i.e. specimens in group M) to make a comparison, the possibility that the change in shape is due to other non-ontogenetic 
variables, such as feeding and burrowing habits or the habitat, is not ruled out.

It has been proven that new identification characters can be derived from the internal anatomy (Fau \& Villier, 2018), but it is necessary to develop more studies of this type in all taxa to establish odontophore as a new valid taxonomic character in any order of asteroids.

Research has tended to focus on external anatomy rather than internal anatomy; working with external morphological characters has resulted in various taxonomic problems between species, specially in some groups with highly variable characteristics such as paxillosids. Although quantitative studies based on traditional ossicle morphometry can be performed (Lawrence et al., 2018), it is complicated to define species based on spination and ossicles whose shape can be affected by the environment or suffer changes due to habitat conditions. Moreover, the search for internal morphological characters has become necessary and represents some advantages according with what has been explored in other echinoderms, such as ophiuroids (Thuy \& Stöhr, 2016; Hendler, 2018; Alitto, Granadier, Christensen, O'Hara, Domenico \& Borges, 2020) as they have shown to be conserved and support robust studies, for example, they may be used for phylogenetic works (Gale, 2011; Thuy \& Stöhr, 2016). Blake (1973) developed the first and only detailed study on the ossicle morphology of the genus Luidia. However, he focused his study mainly on the ossicles of the arm and discussed the disadvantage of working with internal anatomy, due to the use of highly destructive methods. In his study, he did not include the oral frame ossicles for this same reason, and it should be noted that he mentioned that he had rare material that should be preserved as complete as possible. In this sense, this is the greatest challenge we face, since we do not always have the necessary number of specimens to perform that kind of studies, therefore, there is still a lot to be done. The lack of more studies on the internal anatomy of this genus, confirm that the variation in the shape of the odontophore shown here is a precedent for the use of ossicles as additional new taxonomic characters for identification at specific level. The odontophore may be used as an additional character but it is necessary to conduct studies that compare the structure among other species of Luidia. Our results on $L$. superba suggest that more phylogenetic characters can be derived from internal anatomy, and more studies are required for character definition. Regarding the use of Geometric Morphometrics to analyze the odontophore ontogeny, we suggest to use a greater number of ossicles and, consequently, more landmarks and semilandmarks in order to cover most of the ossicle perimeter and to explore other views, such as the lateral or the abactinal, for further studies.

Ethical statement: authors declare that they all agree with this publication and made significant contributions; that there is no conflict of interest of any kind; and that we followed all pertinent ethical and legal procedures and requirements. All financial sources are fully and clearly stated in the acknowledgements section. A signed document has been filed in the journal archives.

\section{ACKNOWLEDGMENTS}

We would like to thank Ma. Esther Diupotex Chong for her technical support at the ENC, ICML, UNAM. To Susana Guzmán Gómez for her technical support with the multifocal photography. To Cirene Gutierrez for the morphometric analysis advice. To CONACYT for the scholarship (number 929010) and to Dave Pawson, William Moser, and the Smithsonian staff for their support. To Berenit Mendoza Garfias and Pietro Tardelli for the SEM photographs. Finally, the authors would like to thank M. G. Lovegrove and A. A. Caballero-Ochoa for the valuable comments on the manuscript's English and scientific content. 


\section{RESUMEN}

\section{Variación ontogenética del odontóforo de Luidia superba (Asteroidea: Paxillosida) y sus implicaciones taxonómicas}

Introducción: El odontóforo es la estructura posicionada entre las placas orales pareadas con las que se articula a través de procesos proximales y distales. Las estructuras de la anatomía interna se pueden usar como caracteres taxonómicos para la diferenciación más precisa entre especies, por lo que es necesario describir la variación de las estructuras a lo largo del crecimiento. Objetivo: Describir la forma y la variación del odontóforo de Luidia superba A. H. Clark, 1917 de ejemplares del Golfo de California depositados en la Colección Nacional de Equinodermos, ICML UNAM. Métodos: Se revisaron un total de 735 ejemplares para describir los caracteres externos y de las cuales se seleccionaron 55 ejemplares, dentro de un intervalo de $\mathrm{R}$ $=14 \mathrm{~mm}$ a $\mathrm{R}=210 \mathrm{~mm}$, de los cuales se extrajeron los odontóforos y fueron analizados utilizando morfometría geométrica. Resultados: Se presentan imágenes de microscopía electrónica de barrido (MEB) de los odontóforos que muestran las variaciones de la forma durante el crecimiento. Se confirmaron diferencias significativas de la forma entre los grupos de tallas mediante un CVA $(p<0.05)$. Conclusiones: Se observa especialización del estereoma a lo largo de la serie ontogenética; la variación en la forma del odontóforo aquí mostrada es precedente para el uso de estructuras de la anatomía interna como nuevos caracteres de identificación.

Palabras clave: Osículos; morfología, zona oral, anatomía interna; morfometría geométrica; Microscopía Electrónica de Barrido.

\section{REFERENCES}

Alitto, R.A., Granadier, G., Christensen, A.B., O’Hara, T., Di Domenico, M., \& Borges, M. (2020). Unravelling the taxonomic identity of Ophiothela Verrill, 1867 (Ophiuroidea) along the Brazilian coast. Journal of the Marine Biological Association of the United Kingdom, 100(3), 413-426.

Alvarado, J.J., Solís-Marín F.A., \& Ahearn, C.G. (2009). Echinoderm (Echinodermata) diversity in the Pacific coast of Central America. Marine Biodiversity, 40(1), $45-56$.

Alvarado, J.J., \& Solís-Marín, F.A. (2013). Echinoderm Research and diversity in Latin America. Berlin Heidelberg: Springer-Verlag.

Benítez-Villalobos, F., Castillo-Lorenzano, F.E., \& González-Espinosa, G.S. (2008). Listado taxonómico de los equinodermos (Echinodermata: Asteroidea y Echinoidea) de la costa de Oaxaca en el Pacífico sur mexicano. Revista de Biología Tropical, 56(3), 75-81.
Benavides-Serrato, M., Borrero-Pérez G.H., \& Díaz-Sánchez, C.M. (2011). Equinodermos del Caribe colombiano I: Crinoidea, Asteroidea y Ophiuoridea. Serie de Publicaciones Especiales de Invemar, 22, 384.

Blake, D.B. (1973). Ossicle morphology of some recent asteroids and description of some West American fossil asteroids. University of California Publications in Geological Sciences, 104.

Blake, D.B. (1989). Asteroidea: Functional morphology, classification, and phylogeny. In M. Jangoux \& J.M. Lawrence (Eds.), Echinoderms Studies 3 (pp. 179186). Rotterdam: Balkema publishers.

Bruzelius, N. (1805). Dissertatio sistens species cognitas asteriarum, quamr. sub praesidio A.J. Retzii. exhibet N. Bruzelius. (pp.1-37). Lundae (formerly know as Retzius, R.J.).

Caso, M.E. (1943). Contribución al conocimiento de los astéridos de México (Master's thesis). Facultad de Ciencias, Universidad Nacional Autónoma de México, Mexico.

Caso, M.E. (1961). Los Equinodermos de México (Doctoral thesis). Facultad de Ciencias, Universidad Nacional Autónoma de México, Mexico.

Caso, M.E. (1979). Los Equinodermos de la Bahía de Mazatlán, Sinaloa. Anales del Centro de Ciencias del Mar y Limnología, Universidad Nacional Autónoma de México, 6(1), 197-368.

Caso, M.E. (1994). Estudio morfológico, taxonómico, ecológico y distribución geográfica de los asteroideos colectados durante las campañas oceanográficas Cortés 1, 2, 3. Anales del Instituto de Ciencias del Mar y Limnología, Universidad Nacional Autónoma de México,12, 1-111.

Clark, A.M. (1989). An index of names of recent Asteroidea-Part 1: Paxillosida and Notomyotida. In M. Jangoux \& J.M. Lawrence (Eds.), Echinoderm studies 3 (pp. 225-347). Rotterdam: Balkema publishers.

Clark, A.M., \& Downey, M.E. (1992). Starfishes of the Atlantic. London, UK: Chapman \& Hall.

Clark, A.H. (1917). Two new astroradiate echinoderms from the Pacific coast of Colombia, and Ecuador. Proceedings of the Biological Society of Washington, 30,171-174.

Downey, M.E. (1973). Starfishes from the Caribbean and the Gulf of Mexico. Smithsonian Contributions to Zoology, 126, 1-158.

Downey, M. E., \& Wellington, G.M. (1978). Rediscovery of the giant sea-star Luidia superba A.H. Clark in the Galapagos Islands. Bulletin of Marine Science, 28(2), 375-376. 
Fau, M., \& Villier, L. (2018). Post-metamorphic ontogeny of Zoroaster fulgens Thompson, 1873 (Asteroidea: Forcipulatacea). Journal of Anatomy, 233, 644-665.

Fau, M., \& Villier, L. (2019). Comparative anatomy and phylogeny of the Forcipulatacea (Echinodermata: Asteroidea): insights from ossicle morphology. Zoological Journal of the Linnean Society, 20, 1-32.

Forbes, E. (1839). On the Asteriadae of the Irish Sea. Memoirs of the Wernerian Society, 8, 114-143.

Gale, A. (2011). The phylogeny of post-Palaeozoic Asteroidea (Neoasteroidea, Echinodermata). Special Papers in Palaeontology, 85, 5-112.

Gale, A. (2015). Evolution of the odontophore and the origin of the neoasteroids. In S. Zamora \& I. Rábano (Eds.), Progress in echinoderm palaeobiology (pp. 67-69). Madrid: Instituto Geológico y Minero de España.

Granja-Fernández, R., Solís-Marín, F.A., Benítez-Villalobos, F., Herrero-Pérezrul, M.D., \& López-Pérez, A. (2015). Checklist of echinoderms (Echinodermata) from the Southern Mexican Pacific: a historical review. Revista de Biología Tropical, 63(2), 87-114.

Gray, J.E. (1840). A synopsis of the genera and species of the class Hypostoma (Asterias, Linnaeus). Annals of the Magazine of Natural History, 6, 275-290.

Hendler, G. (2018). Armed to the teeth: a new paradigm for the buccal skeleton of brittle stars (Echinodermata: Ophiuroidea). Contributions in Science, 526, 189-311.

Hulings, N.C., \& Hemlay D.W. (1963). An investigation of the feeding habits of two species of sea stars. Bulletin of Marine Science of the Gulf and Caribbean, 13, 354-359.

Honey-Escandón, M., Solís-Marín, F.A., \& LaguardaFigueras, A. (2008). Equinodermos (Echinodermata) del Pacífico Mexicano. Revista de Biología Tropical, $56(3), 57-73$.

Jangoux, M. (1982a). Food and feeding mechanisms: Asteroidea. In M. Jangoux \& J.M. Lawrence (Eds.), Echinoderm Nutrition (pp. 117- 159). Rotterdam: Balkema publishers.

Jangoux, M. (1982b). Digestive systems: Asteroidea. In M. Jangoux \& J.M. Lawrence (Eds.), Echinoderm Nutrition (pp. 235 -248). Rotterdam: Balkema publishers.

Lawrence, J.M. (2013). Luidia. In J.M. Lawrence (Ed.), Starfish. Biology and ecology of the Asteroidea (pp. 109-119). Baltimore: Johns Hopkins University Press.

Lawrence, J.M., Cobb, J.C., Herrera, J.C., Duran-Gonzalez, A., \& Solís-Marín, F.A. (2018). Morphological comparison of Astropecten cingulatus and a new species of Astropecten (Paxillosida, Astropectinidae) from the Gulf of Mexico. Zootaxa, 4407(1), 86-100.

Maluf, L.Y. (1991). Echinoderm fauna of the Galápagos Islands. Chapter 16. In M. J. James (Ed.), Galápagos Marine Invertebrates (pp. 345-367). New York: Springer Sciences.

Martín-Cao-Romero, C., Solís-Marín, F.A., CaballeroOchoa, A.A., Hernández-Díaz, Y.Q, López, L., \& Zúñiga-Arellano, B. (2017). New echinoderm remains in the buried offerings of the Templo Mayor of Tenochtitlan, Mexico City. Revista de Biología Tropical, 65(1), 168-179.

Müller, J. \& Troschel, F.H. (1842). System der Asteriden.1. Asteriae. 2. Ophiuridae. Vieweg: Braunschweig, 134 pp.

O'Neill, P. (1989). Structure and mechanics of starfish body wall. Journal of Experimental Biology 147, $53-89$.

Perrier, E. (1884). Mémoire sur les étoiles de mer recueilliés dans la mer des Antilles et le golfe du Mexique: durant les expéditions de dragace faites sous la direction de M. Alexandre Agassiz. Archives (Muséum national d'histoire naturelle (France)). 2. sér., 6,127-276.

Puppin-Gonçalves, C.T., Rocha, M.A.L., Alencar, C.E., Moraes, S.A., Araújo, P.V., \& Freire, F.A. (2020). Niche modeling remarks of Luidia senegalensis (Lamarck, 1816) (Asteroidea, Luidiidae) after 30 years of its first capture in the northeastern Brazilian coast. Latin american journal of aquatic research, 48(3), 497-505.

Sladen, W.P. (1889). The Asteroidea. Report on the scientific results of voyage of H. M. S. "Challenger". Zoology, 30, 1-935.

Solís-Marín F.A., Laguarda-Figueras, A., Durán-González, A., Ahearn, C.G., \& Torres-Vega, J. (2005). Equinodermos (Echinodermata) del Golfo de California, México. Revista de Biología Tropical, 5(3), 123-137.

Thuy B, Stöhr S. (2016). A new morphological phylogeny of the Ophiuroidea (Echinodermata) accords with molecular evidence and renders microfossils accessible for cladistics. PLoS One, 11 (5), e0156140.

Turner, R.L., \& Dearborn, J.H. (1972). Skeletal morphology of the mud star, Ctenodiscus crispatus (Echinodermata: Asteroidea). Journal of Morphology, 138(2), 239-262.

Viguier, C. (1878). Classification des Stellerides. Comptes rendus hebdomadaires des séances de l'Académie des sciences, 86, 681-683. 